\title{
THE INTERPRETATION OF THE AUTHORIAL CREATION OF VLADIMIR VYSOTSKY ON CONTEMPORARY MOSCOW STAGES
}

\author{
ZUZANA SPODNIAKOVÁ \\ Institute of Theatre and Film Research, \\ Art Research Centre of the Slovak Academy of Sciences, Bratislava
}

\begin{abstract}
The study presents an overview and analysis of contemporary Moscow productions inspired by the personality and work of the legendary Russian actor and poet of the latter half of the $20^{\text {th }}$ century, singer and songwriter Vladimir Semyonovich Vysotsky (1938 - 1980). The authoress covers both the older productions which have been on the repertoires of theatres for several years and more recent productions staged this year on the occasion of the artist's unlived $80^{\text {th }}$ birthday. Researching on the productions by different theatre makers, staged by various theatres and drama ensembles, points at the importance and up-to-dateness of the creative legacy of Vladimir Vysotsky and at the significance of him as a personality that has become a legend and a component part of the cultural history of Soviet and post-Soviet eras. The productions constitute a significant part of the unwavering cult of his personality.
\end{abstract}

Key words: Vladimir Semyonovich Vysotsky, contemporary Russian theatre, authorial song, $20^{\text {th }}$ century Russian poetry

Vladimir Semyonovich Vysotsky (1938 - 1980), who would have turned 80 this year, was among the most distinctive Russian actors, poets and representatives of authorial song of the latter half of the $20^{\text {th }}$ century. He became a legend during his life. He is the author of about six hundred songs and poems and he is referred to as "Pushkin of the $20^{\text {th }}$ century," or "Bob Dylan of the Soviet Union"1 and, until his tragic death, he used to "sing about the times" 2 he had actually lived. His poetry portrayed various human stories of the ordinary men of his time. Using the words of the literary critic Sergei Chuprinin, he was the author of "Vysotsky theatre," 3 which was the "encyclopaedia of the Russian way of life at a time of doldrum" and an "encyclopaedia of the moods of modern man". ${ }^{4}$ The poet Yevgeni Yevtushenko called

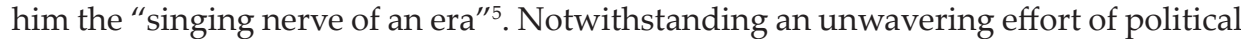
and power authorities, Vysotsky could not be put to silence. The civic engagement of

${ }^{1}$ Interview with Dan Rather in 60 minutes, Studio CBS New York, July 1976, broadcast on 20 February 1977. Cit. according to Vladimir Vysotsky : N'yu York-Moscow [DVD]. Moskva : Bomba Miuzik, 2007.

${ }^{2}$ ROZHDESTVENSKY Robert. Cit. according to FOKIN, Pavel (ed.). Vysotsky: Bol'no mne za nash SSSR... Sankt Peterburg : Amfora, 2012, p. 7.

${ }^{3}$ CHUPRININ, Sergei. Vakancia básnika. In TOKÁR, Milan. (ed. a transl.). Taký bol Vysockij. Translation of verses by Lubomír Feldek, in language cooperation with Milan Tokár. Bratislava : Obzor, 1990, p. 264. ISBN 80-215-0069-7.

${ }^{4}$ Ibid.

${ }^{5}$ YEVTUSHENKO, Yevgeni. Poyushchi nerv nashei epochi. In SAFRONOV, Anatolij. (ed.). Vospominanija Vladimira Vysockogo. Moskva : Sovetskaja Rossija, 1989, p. 355. ISBN 5-268-00829-3. 
his texts resonated in society and despite the ban, people would be listening to them from unofficial tape recordings. At a time of unfreedom these texts were a source of hope and joy. These social attributes and the dramatic nature of "Vysotsky theatre" of songs and poems surface principles and signs similar to contemporary documentary theatre and theatre producers build on that to a varying degree. The purpose of documentary theatre and docudrama is a distinct civic engagement, a critical reflection of the time lived with an intention to improve the quality of life. Their authenticity is enhanced by the use of and work with the colloquial language. Vysotsky, too, uses street language, which he transposes into poetic form. Creative professionals would use it depending on the poetics of a production. The fact that the work of Vysotsky is not banned any more ${ }^{6}$ does not belittle its significance. Its artistic legacy remains very much with us. However, theatre producers wishing to stage his works must cope with the unwavering cult of Vysotsky's personality.

The productions that dramatize Vysotsky's songs, poems, and prose texts are, to a varying degree, interconnected with a broad range of biographical facts of his life. Vysotsky's texts are oftentimes incorporated into the texts of other authors. A lot of times, productions are re-enactments of the fragments of the most notable presentations of his theatre creations or references to other productions, radio plays or films that he starred in. Theatre makers employ the principles of his synthetic style of acting, which he also used in his songs and poetry writing and performing. All productions based on Vysotsky's texts interconnect several art forms, i.e. acting, poetry, singing, play on musical instruments. The elements of epic theatre and Bertolt Brecht's alienation effect are quite frequently incorporated in the production concept. On other occasions, actors would identify themselves with Vysotsky's character and the characters of stories in his songs and poems in a manner similar to verbatim method employed in documentary theatre. The connection between this method and Vysotsky's creation is not direct, it is the use of verbatim as an anogy to oral history, when actors internalise performed texts as if speaking for themselves, which was a method used by Vysotsky to perform his texts. With respect to form, this method does not correspond to an authorial and artistically stylised text. The performers' authentic identification with the text takes place especially at inner, psychological level. In productions, Vysotsky would oftentimes perform the author's role and be a witness of the fates of the characters he created. He is present on stage via the recordings of his songs, via the preserved projections of productions, interviews and other performances. The productions frequently bridge the legacy of his personality and creation with the present, to underscore their persisting up-to-dateness.

${ }^{6}$ The Nerve, the first collection of Vysotsky's songs and poems, was published in Moscow a year after his death (1981). In 1987, the USSR State Prize was bestowed on him in memoriam, for the performance of songs and rendition of Gleb Zheglov in a film adaptation in five parts of the novel by Arkadi and Georgi Vayner Mesto vstrechi izmenit nelzya [The Meeting Place Cannot Be Changed], direction Stanislav Govorukhin, Odesskaja kinostudija, 1979. The prize was collected by his father Semyon Vysotsky. 


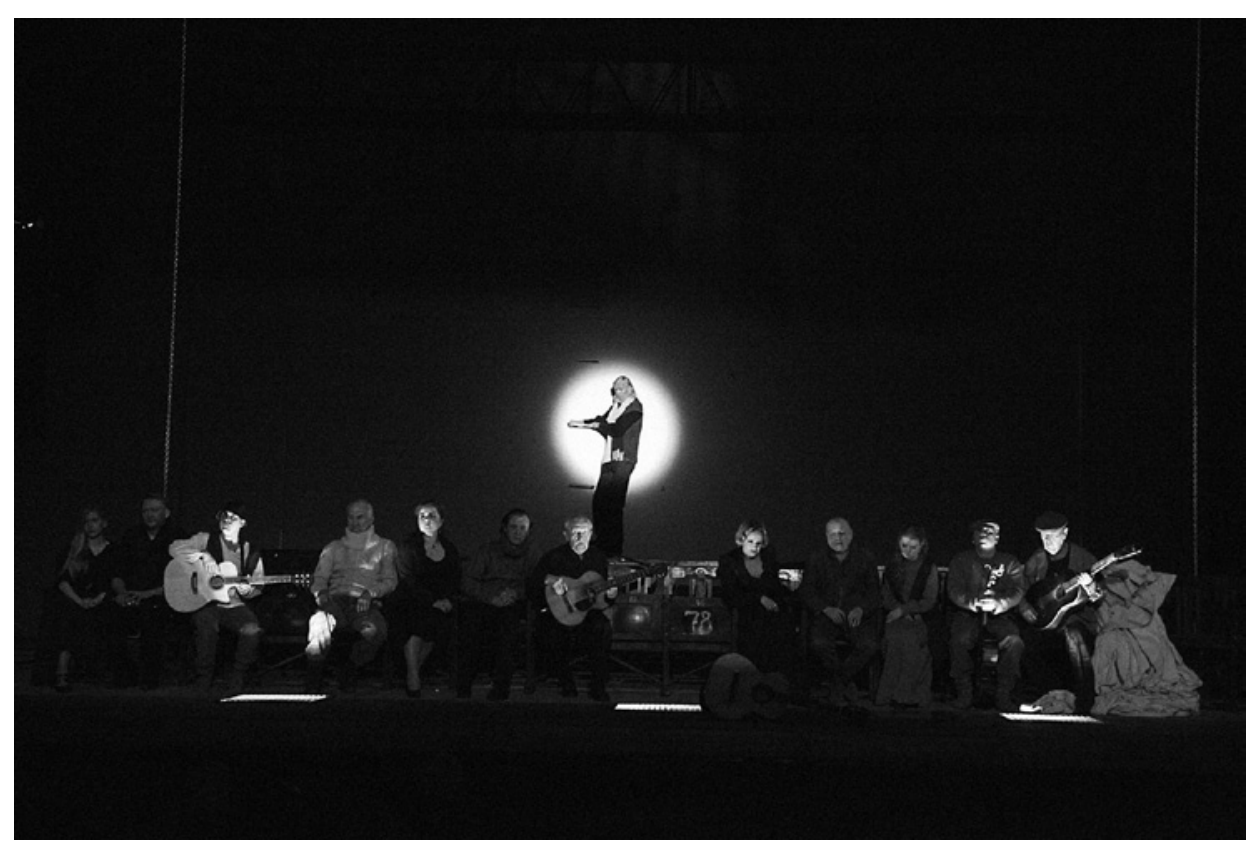

Yuri Lyubimov: Vladimir Vysotsky. Moscow Theatre of Drama and Comedy on Taganka Square, premiered on 25 July 1981. Direction Yuri Lyubimov. Photo by Aleksandr Sternin. Theatre archives.

\section{The First Requiem for Vysotsky on Taganka Theatre}

The first production dedicated to Vysotsky after he passed away, was mounted on stage he had worked for almost his entire professional acting career and on which he performed his most famous roles, of the Moscow Theatre of Drama and Comedy on Taganka Square. Almost from the outset of its operation under artistic director and chief director Yuri Lyubimov, a distinctive dramaturgic line of the theatre was made up of productions dedicated to Russian poets - to classics Alexander Pushkin, Vladimir Mayakovsky or Sergei Yesenin, to the war generation poets and to the poets of the latter half of the $20^{\text {th }}$ century. A need to dedicate a production to a peer and friend who dedicated his life to Moscow Taganka Theatre as both actor and poet, was an artistic and personal need of the ensemble.

An idea to preserve Vysotsky's presence on Taganka stage was brought forth by Lyubimov a few days after bidding farewell to Vysotsky (28 July 1980). As was customary then, the theatre had to fight for a long time with the decision-making authorities, to get a permission to put the production on stage. It was extremely difficult for Lyubimov to be granted the permission by Yuri Andropov, the then Secretary General of the Central Committee of the Communist Party of the Soviet Union, to at least perform a poetic commemorative composition Vladimir Vysotsky on the occasion of the first anniversary of his death on 25 July 1981. The next production could have been played on 25 January 1989 at the earliest, on the day of the unlived fifty-first birthday of the actor and poet, and ever since, it has been performed until the present 
with a changed cast. Lyubimov, being the director and author of the composition, had the entire drama ensemble of Taganka Theatre engaged in the production, all of whom were Vysotsky's long-time colleagues and friends who for many years used to perform with him side by side.

The backbone of the concept was the "tragic tension of [Vysotsky's, author's note] leave in the days that followed"7. Initially, the production's title was Moscow Bids Farewell to a Poet [Moskva proshchaetsia s poetom]. The purpose was to "have the production ascertain Vysotsky as a poet. A poet who grew to be an actor of the Taganka Theatre." ${ }^{8}$ This is aptly alluded to in the production subtitle Gamlet bez Gamleta ili poslednyaya rol' poeta [Hamlet without Hamlet, or the Poet's Last Role]. This time, there was no big curtain hanging over the stage like in Hamlet, but a reclining auditorium (modified to the rather small stage of the Taganka Theatre). It consisted of real movie seats, in places covered by a large white sheet. The stage design in both productions was the work of David Borovsky (Brodsky). The auditorium, just like the curtain in Hamlet, is both metaphoric and concrete: in the production finale, it is lifted and the stage remains empty just like in Hamlet.

Lyubimov, when casting Vysotsky in the role of Hamlet, consciously worked on the identification of the character of the Danish prince with poet Vysotsky. ${ }^{9}$ In the composition Vladimir Vysotsky, the director continued the process of identification when he picked up on the finale of Shakespeare's tragedy. In it, after Hamlet's final words "The rest is silence," Lyubimov broke the "silence" of Hamlet's death by Vysotsky's taped voice. The principle employed in the finale of the production of Shakespeare's play was further developed as a backbone concept of the above commemorative production. While the storyline is unfolding, Vysotsky is present on stage thanks to recordings. He performs his songs that alternate with his recorded replies to a survey carried out in the theatre. The fragments of the recordings of his voice from Hamlet scenes are heard, including the posthumous words of the text of Scene 4, Act 4 (the sequence of lines is switched). Through them, in Shakespeare's tragedy, Vysotsky passed over a clear message to contemporaries and to the generations to come. The message accords with his work and it is being repeated in the composition. He makes it clear that the biggest of all tragedies is life without a purpose:

"Sure, he that made us with such large discourse,

Looking before and after, gave us not

That capability and godlike reason

To fust in us unused.

What is a man

If his chief good and market of his time

\footnotetext{
${ }^{7}$ Moscow Theater of Drama and Comedy on Taganka. ... ni edinoyu bukvoy ne lgu [programme booklet]. Moscow : MDKDNT, year and page numbers not specified.

${ }^{8}$ Ibid.

${ }^{9}$ For his rendition of Hamlet (premiered on 29 November 1971), Vysotsky who performed him two hundred and twenty one times in nine theatre seasons, was awarded Grand Prix at the Belgrade International Theatre Festival BITEF in 1976, and in 1980, he was awarded a prize at the Warsaw Theatre Meetings Festival. Similarly to his costume of Hamlet, Vysotsky was buried at the Vagankovskoye Cemetery in Moscow clad in a new pair of black corduroy pants and a black pullover brought by his spouse Marina Vlady from Paris.
} 
Be but to sleep and feed? A beast, no more." 10

The backbone of the commemorative composition Vladimir Vysotsky is the story of Hamlet by Shakespeare. Almost all prosaic parts of the play have been put to use. Its characters - Gertrude, Claudius, Polonius or Ophelia perform Hamlet scenes "without Hamlet". He responds by voice recorded on tape. Shakespeare's text applied to Vysotsky's story of actor and poet who became a firm part and legend of the cultural history of Soviet and post-Soviet eras, acquired a completely new meaning. It portrays Vysotsky, not Hamlet, it narrates how Vysotsky was banned, humiliated, silenced and censored. The text of the English dramatist is slightly modified in places, to match Vysotsky's biography. The parts of Hamlet in verse were replaced by lines written by poet Vysotsky, picked from a broad range of his creation. Once again, the work and personalities of William Shakespeare, Boris Pasternak, and Vladimir Vysotsky were blended together, which was also the case of Hamlet directed by Lyubimov and with Vysotsky in the lead role. At that time, Lyubimov opted for the translation by the then banned poet and prose writer Boris Pasternak. In the opening scene, Vysotsky even sung the text of Pasternak's poem Hamlet from his novel Doctor Zhivago, which he set to music. One banned poet sung the lines of another banned poet. Vysotsky's Hamlet became a hero who waged an uncompromising war against the illness of his time and he continued the struggle in composition Vladimir Vysotsky.

A component part of the script was until then unpublished poetry which even Taganka actors had not come across. The recordings on which Vysotsky sings his own lyrics alternate in the composition with the live performance of his colleagues - actors. He was changed to a role performed by them. They perform the story of Vysotsky and narrate the stories he had been writing about in his songs and poems. Lyubimov works with the storyline and compact characters of protagonists. Some of them are dramatized on stage, which was the case of his previous directions of poetic texts. Dramatic tension in a composition is enhanced by employing the principle of divergent opinions, which Vysotsky was exposed to both as author and actor. $\mathrm{He}$ builds it via the tension between the presence and the absence of Vysotsky, via his being and not being on stage: "To be or not to be?" which is repeated in English twice. On the one hand, actors take action as if the lead actor rendering Hamlet and their colleague and friend Vysotsky were physically present (together with him they sing his songs and engage in dialogues with him), only to realise that he is not there. For instance, in a scene in which the well-known song Bolshoi Karetny [Bolshoi Karetny Lane], (1962) is sung, they ask him, with the song lyrics: "Where are they now, your seventeen years?", "And where've your troubles always been?", "Your black hand gun - anywhere?" Each time, Vysotsky's singing voice would reply from a recording: "On Bolshoi Karetny." However, after the question: "And where aren't you today?"11 there follows no reply, there is only silence.

${ }^{10}$ SHAKESPEARE, William. Hamlet [online]. Translation Jozef Kot. Bratislava : HEVI, 1994, p. 110. Available at https://cloud.edupage.org/cloud/William-Shakespeare---Hamlet.pdf?z\%3Ar4775gKnrpQOCn60fF\% 2Bm8XWGZpiFmmZgu1CKxzH2A5IozkdUrUA0Uz9QEpDcNY8Q.

${ }^{11}$ An excerpt from Vladimir Vysotsky's song Na Bolshom karetnom [On Bolshoi Karetny Lane], (1962). Translation by Lubomír Feldek, in language cooperation with Milan Tokár. Cit. according to TOKÁR, Milan (ed. a transl.). Taký bol Vysockij, p. 156. 
In conclusion, Lyubimov closes the circle of the connection between the production Hamlet and the production dedicated to Vysotsky: where Hamlet had started, the commemorative composition Vladimir Vysotsky came to an end. All actors are seated at the back, by a wall of white bricks. It was exactly the same place where Vysotsky would be seated with a guitar before Hamlet opened up and where he would be dying towards the close of the production. In the centre, between the actors, there was a guitar standing against a wall. It stayed there, all forlorn. Throughout the production, his song Koni priveredlivye [Fastidious Horses, 1972] is being heard, which is a portrayal of galloping horses he is unable to stop. In it, Vysotsky confessed to his life and creative endeavours and the song foreshadowed his tragic destiny:

"Slow your gallop, oh my horses! Slow your gallop, I say!

Don't you listen to my stinging whip!

But the horses I was given, stubborn and so unforgiving,

Can't complete the life I'm living, can't conclude the verse I'm singing." 12

Today, Lyubimov's requiem for Vysotsky epitomises a requiem for one-time Taganka Theatre. As was noted by the theatre scientist and film critic Maya Turovskaya: "Hamlet has become part of Vysotsky myth just like Vysotsky has become a component part of the legend about the Taganka Theatre. In this sense, the death of the Danish prince enhanced the significance of Vysotsky for Russia and marked the end of an era." ${ }^{13}$

\section{A Second Requiem for Vysotsky, Again in the District of Taganka}

Reflecting on the one-time bond between Vladimir Vysotsky and the Taganka Theatre, a "literary and scenic composition"14 V.V.S. : Vysotsky Vadimir Semyonovich was also devised by the Commonwealth of Taganka Actors Theatre (1992). ${ }^{15}$ After the "Taganka divorce,"16 the new ensemble moved to a new part of the building. Both theatres based in one street, with entrances next to each other, present their own commemorative compositions to the viewer, dedicated to their close peer and friend.

The production dedicated to Vysotsky was put on stage to mark his $60^{\text {th }}$ unlived birthday. It was premiered on 25 January 1998, and much like the production of the Theatre of Drama and Comedy on Taganka Square, it has been on the repertory of

${ }^{12}$ An excerpt from Vladimir Vysotsky's song Koni priveredlivye [Vrtošivé kone], (1972). Slovak translation Lýdia Vadkerti-Gavorníková. Cit. according to TOKÁR, M. (ed. a transl.). Vladimír Vysockij : Môj Hamlet, p. 134.

13 TUROVSKAJA, Maja. Hamlet : la mort est là, elle est à l'oeuvre. In PICON-VALLIN, B. (ed.). Lioubimov. La Taganka. Paris : CNRS Éditions, 1997, p. 324. Cit. according to LINDOVSKÁ, Nadežda. Príbeh režiséra, príbeh Taganky, príbeh divadla a spoločnosti... In Slovenské divadlo, 1999, Vol. 47, Issue 1, p. 100.

${ }^{14}$ Teatr Sodruzhestvo akt'orov Taganki. V.V.S. : Vysotsky Vladimir Semyonovich [programme booklet]. Moskva : SAT, year of publication and page numbers not indicated.

${ }^{15}$ After Vysotsky's death, the conflicts between the theatre and their fatherland reached their apex. Yuri Lyubimov emigrated (1984 - 1988), his post of director during the subsequent three years (1984 - 1987) was taken by director Anatoli Efros, but he was never accepted by theatre professionals. The one-time strength and social significance of "the neglected ensemble," was gradually lost due to political changes. The theatre, after Lyubimov's comeback from emigration, was never restored to a theatre of Vysotsky's time.

${ }^{16}$ MICHALOVA, Ella. V Granicach krasnogo kvadrata. Moskva : Izdatelskij dom Rodionova, 2007, p. 374. ISBN 978-596730073-8. 
the new ensemble ever since. Its author, director, stage designer and one of the main protagonists is Nikolai Gubenko, the theatre's artistic director. He used to star in Lyubimov's commemorative poetic composition Vladimir Vysotsky. He also cast other actors in the production, who used to perform on the stage of the old Taganka Theatre together with Vysotsky, for example, Zinaida Slavina, Mikhail Lebedev, Viktoriya Radunskaya, Alla Bogina, Lidia Savchenko or Polina Fokina.

Gubenko, just like Lyubimov, picks on the tradition of poetic productions of the Taganka Theatre. Aside from singing and the declamation of the texts and lyrics of Vysotsky's poems and songs, he also puts them on stage. According to his words: "Each of Vysotsky's songs is a small performance."17 Gubenko also revisits song lyrics from various cycles, starting with Vysotsky's underworld cycle of songs ("blatnye pesni", or outlaw songs about life on the wrong side of the law $)^{18}$, through lyrical cycle, down to war cycle. They all express Vysotsky's "love of fatherland and loyalty to it"19. Gubenko, like Lyubimov, alternates the performance of Vysotsky's lyrics with the audio recordings of Vysotsky's singing. The dramaturgic sequencing of songs and poems does not create a linear continuum and a chronological, compact storyline. Some songs are sequenced by genre and fleetingly, their stories connect, only to have other self-contained micro-stories unfold.

While Lyubimov's composition employed the allusion to Vysotsky's rendition of Hamlet, Gubenko alludes to an earlier, likewise legendary, role performed by Vysotsky, to Khlopusha. He performed him in Lyubimov's production of Yesenin's long poem Pugachev (1967). In the role of a convict sent to the Urals, Vysotsky fully demonstrated his talent of actor and poet with a potential to work with the word of poetry at drama level. In the audiences' eyes, Vysotsky's performance of Khlopusha's monologue turned him into the main hero, replacing Pugachev, who had been rendered by Gubenko earlier on. Gubenko, in the composition V.V.S. : Vysotsky Vladimir Semyonovich, alludes to the production Pugachev through stage design. The stage is set with wooden platforms, slanting towards the middle of the stage, similar to the platform in Lyubimov's production. There is a high wooden staircase standing in the middle, with a bell hanging from above, much like the one used in Pugachev to announce executions. The actors, coming and going up and down the staircase, would sound the bell, usually with the scene opening or closing. The staircase rises to an opening between two windows in the wall of a house. The wall on the stage creates the setting of Moscow backyards where a lot of Vysotsky's texts unfold.

The most powerful presence of Vysotsky on stage is felt in the production finale. A large white sheet the size of the entire stage soars over the stage. It helps create the effect of shadow theatre. In it, the actor's (Vysotsky's) silhouette, holding a guitar, is reflected, while ascending the stairs, as if to heaven. Vysotsky's recorded voice, using the lyrics from the song Pamiatnik [The Monument, 1972], asks the audience: "Do you really need me like this, after death?" ${ }^{20}$ After the question is put, the sheet falls onto

\footnotetext{
${ }^{17}$ Cit. according to http://www.taganka-sat.ru/?ITEM_ID=2996 [25 September 2017].

${ }^{18}$ Backyard, urban folklore songs, typical of the Russian underworld, portraying brawlers in the backyards of Moscow residential quarters.

${ }^{19}$ Ibid.

${ }^{20}$ Loosely translated by the authoress. The translation by Lubomír Feldek is: "Vyhovujem vám akurát taký vo večnosti?" Cit. according to TOKÁR, Milan (ed. a transl.). Taký bol Vysockij, p. 195.
} 
the stage, the actors lift it again, and the recorded singing of the song Fastidious Horses is heard (exactly as in Lyubimov's finale). The sheet soars up high over the stage. Now the actor who walked up the staircase as Vysotsky earlier on, is seen descending and singing the song Esche ne vecher [It's Not Over, 1968]. Other actors join in. The sheet above the stage changes to a projection screen showing the portrait of Vysotsky. The white sheet is not illuminated any longer, only his image is glowing in the darkness. The actors catch each other by the shoulder and together with the recording of Vysotsky singing, they conclude the performance uttering a line from his song "The captain was right, it's not over until it's over" ${ }^{\prime 21}$. Vysotsky's face remains above the stage during the final bow.

\section{Other Remembrances of Vysotsky, Not Far behind the Taganka Theatre}

In the latter half of the 1980s, the early film documents about Vysotsky were released. Towards the close of the decade, magazines and books were published, covering Vysotsky's acting career and prose writing. The memoirs by his colleagues, friends and family members were published as parts of collections of his poems and songs, and also in articles published in magazines and books. In 1989, Soyuz Teatral'nykh Deyateley Rossiyskoy Federatsii published a book of memoirs of Alla Demidova, actress of the Taganka Theatre entitled Vysotsky, kak znayu i lyublyu [Vysotsky, the One I Know and Love] and Progress Publishers published in Russian translation a book of memoirs of Vysotsky written by his third wife Marina Vlady (born Marina Catherine de Poliakoff-Baydaroff) entitled Vladimir ili prervanny polyot [Vladimir, or the Aborted Flight]. Both the authoresses read their memoirs live as dramatized reading, thus starting a tradition of their dramatization.

Two productions dedicated to Vysotsky, to a large extent based on the above books, i.e. Ya, Vysotsky Vladimir...22 [I, Vysotsky Vladimir] and Rayskye yabloki (the title Apples from the Garden of Eden was taken from Vysotsky's song written in 1977) continue to be performed by the V. Vysotsky State Cultural Centre-Museum "Vysotsky's House on Taganka." ${ }^{23}$ It is located in Vysotsky Street No. 3, behind the buildings of the Taganka Theatre and the Commonwealth of Taganka Actors Theatre. Both productions are intimate duets of an actor and an actress with a minimalist stage design. On the stage a kaleidoscope of published remembrances of the life and creation of Vysotsky is reanimated. Memories overlap with his songs and poems. They portray an artist and private individual, his outer and inner worlds. In both productions, the story is framed by the beginning of the relationship between Vysotsky and Marina Vlady and by his untimely death. The productions do not aim at an illusory reality or documentary accurateness. Above all, the actors are given an opportunity to get emotionally engaged in the moments taken from private and professional lives of Vysotsky and to communicate them to the audiences.

\footnotetext{
${ }^{21}$ Loose translation by the authoress.

${ }_{22}$ The play's original title was taken from the name of Vysotsky's song Lyublyu tebya seychas... [I love you now...], (1973).

${ }^{23}$ Founded in 1992. Since 1996, the director has been Vysotsky's son, Nikita Vysotsky.
} 


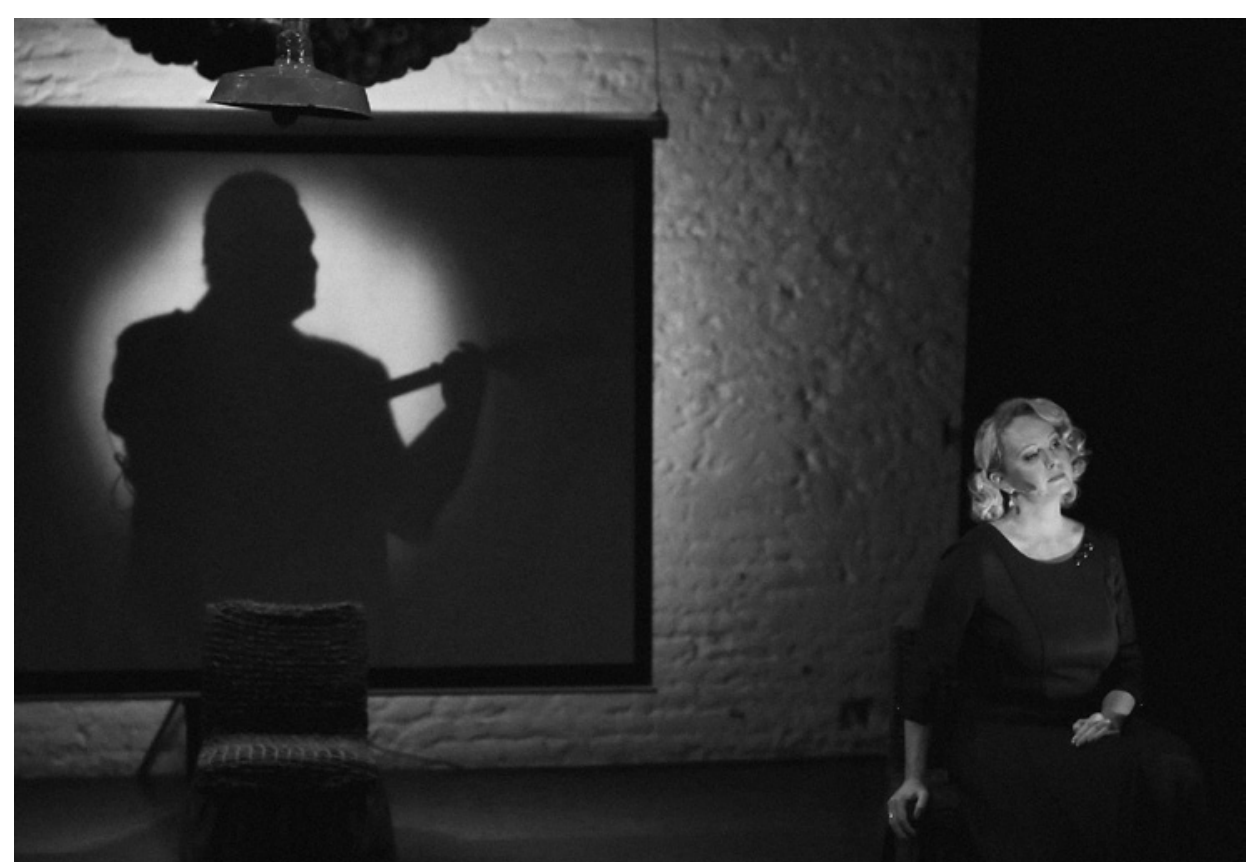

Rashid Tugushev: Rayskye yabloki [Apples from the Garden of Eden]. V. Vysotsky State Cultural Centre-Museum "Vysotsky's House on Taganka", premiered on 25 July 2005. Lyudmila Tatarova-Djigurda, Alexei Zykov. Direction Rashid Tugushev. Photo by Anvar Galeyev. Theatre archives.

The production Ya, Vysotsky Vladimir... [I, Vysotsky Vladimir...] was premiered in $1990 .{ }^{24}$ Initially, it was performed on the $25^{\text {th }}$ day of month (which is done by a lot of theatres), in honour of Vysotsky's birthday and death $\left(25^{\text {th }}\right.$ January $1938-25^{\text {th }}$ July 1980). Its author and director is actor and a close friend of Vysotsky, Valeri Zolotukhin, from the Taganka Theatre, who has also written several memoir books about Vysotsky. The play's prosaic parts are mostly based on Marina Vlady's book. A copy in Russian language is present on stage throughout the entire production. Both the actors, Lyubov Chern'yaeva-Chirkova and Valeri Chern'yaev, come to the stage, each for herself/himself. In a civil manner, they introduce themselves to the audiences and introduce the performance and the production concept. In their words, the concept is about the acting of a "love story" of Vysotsky and Vlady, and the excerpts from Vlady's book, Vysotsky's songs and poems are selected to serve the purpose. A lot of them were dedicated to her or to their shared experiences. During the production, the actors identify themselves with the characters. If they do not perform in a scene, they step out of character but remain on the stage.

An audio recording of Vysotsky's legendary monologue of Khlopusha from Pugachev is incorporated in the production. The audio recording switches to Chern'yaev's live monologue. He alternated Khlopusha with Vysotsky while being with the Taganka Theatre and completely took the title part over after his death.

\footnotetext{
${ }^{24}$ The exact date and venue of the premiere has not been established from the sources available.
} 
When the production is over, from the stage he shares his remembrances of the early days as actor of the Taganka Theatre and gives an account of his doubles and alternations of Vysotsky.

The second production, Rayskye yabloki [Apples from the Garden of Eden] directed by Rashid Tugushev, was produced under the artistic guidance of Nikita Vysotsky, son of Vladimir Vysotsky. ${ }^{25}$ It was premiered on 25 July 2005, to mark the $25^{\text {th }}$ anniversary of the actor's death. The text of Rashid Tugushev is based on the books by Marina Vlady and Alla Demidova and also on the memoirs of Lyudmila Abramova, second wife of Vysotsky. Intensive emotions of their memories are brought to life in the monologues of the main female heroine (Lyudmila Tatarova-Djigurda ${ }^{26}$ ) and are confronted with the character of Vysotsky present on stage (Alexei Zykov' ${ }^{27}$ ).

The dramatic line of this "musical production" 28 evolves at two interconnected levels. The first one entails Vysotsky's view on his life as actor and poet and the singer of authorial songs, the second one presents the opinions on his life shared by the women who were closest to him. According to the producers, the concept of the production is based on "a dialogue with the poet and his fictitious response to the remembrances of him through his songs." ${ }^{29}$ The storyline is divided into three mutually connected parts, i.e. the early period of the poet's creation when he socialised with his friends-artists in Bolshoi Karetny Lane ${ }^{30}$, his life on the stage of the Taganka Theatre and lastly, his "mythological and song dialogue with the viewer." 31 After each part there follows a video projection of the documentary video clips with Vysotsky. The performance features twenty of his songs, from his early and less popular songwriting to the best-known songs. Oftentimes, songs are the vehicle of the storyline and shifts in the relationship between both heroes. The third part is a mono drama of the actor playing the guitar. It is a monologue composed of Vysotsky's cult songs. Through them, Zvykov guides the audiences through Vysotsky's personal life, feelings, dramatic turns and recollections enshrined in his lyrics. When performing the songs, Zvykov would even mimic Vladimir Vysotsky's peculiar pronunciation by lengthening and stressing consonants. It makes the viewer think he/she is truly listening to Vysotsky. In conclusion, actress Tatarova-Djigurda sings Vysotsky's song Pesnya Mar' $i$ a capella (alternative title Mariushka, 1974), which is a song about waiting for a sweetheart who is on the battlefront.

The stage in the Vysotsky's House on Taganka is open to the performance of Vysotsky's authorial creation and to the commemoration of his personality by young

${ }^{25}$ A stand-alone project associating the performers of Vysotsky's creation Planeta Vysotskogo is to be given credit for putting it on stage.

${ }^{26}$ Actress Lyudmila Tatarova-Djigurda is the fourth actress cast in the role. The first one was actress Regina Myannik.

${ }^{27}$ Singer and musician Alexei Zykov has been cast in the role from the outset. He is regarded as one of the best contemporary performers of Vysotsky's songs. In 2000, he was awarded a prestigious Grand Prix in Chicago, for "The best performance of the songs of Vysotsky."

28 Cit. according to http://www.visotsky.ru/8-novosti/207-25-marta-2017-spektakl-rajskie-yabloki. (1 September 2017).

${ }^{29}$ Cit. according to https://vk.com/event55808850 (11 December 2017).

${ }^{30}$ Between 1949 and 1955, Vysotsky used to live in a house in this street together with his father and his second wife Yevgeniya Vysotskaya-Likhalatova. The flat of his neighbour, director Levon Kocharyan, was a meeting place of artists and the earliest listeners of his songs.

${ }^{31}$ Cit. according to https://vk.com/event55808850 (11 December 2017). 


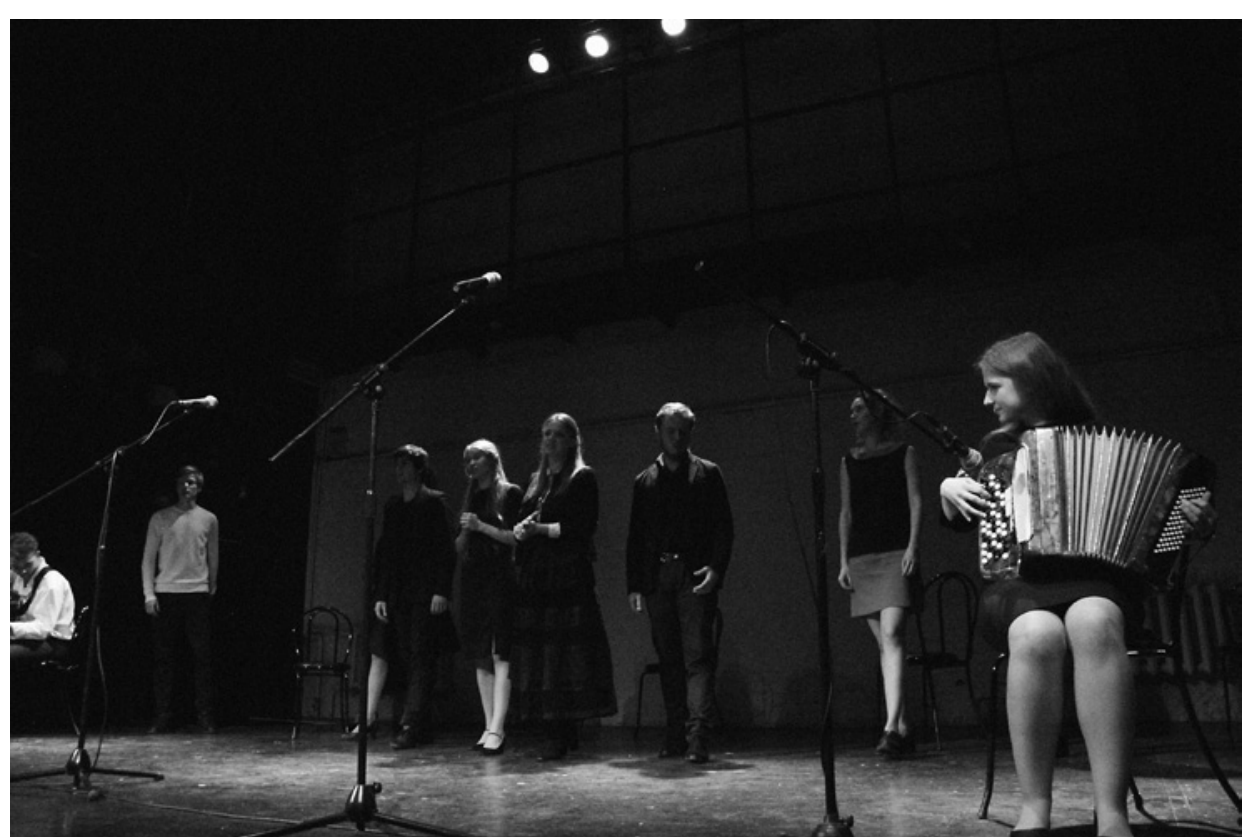

Nikita Vysotsky: Zdravstvuyte, Vladimir Vysotsky... [Hello, Vladimir Vysotsky...]. V. Vysotsky State Cultural Centre-Museum "Vysotsky's House on Taganka", premiered on 4 November 2016. Gleb Romashevsky, Denis Davydov, Ivan Stepanov, Tatyana Volkova, Nataliya Koloskova, Artur Marchenko, Svetlana Vishnyakova, Mariya Derbina. Direction Nikita Vysotsky. Photo by Irina Mavrova. Theatre archives.

theatre professionals. The production Zdravstouyte, Vladimir Vysotsky... [Hello, Vladimir Vysotsky...] $]^{32}$, premiered on 4 November 2016, is frequently performed by the Youth Experimental Theatre Masterskaya N. L. Skorika (former students of acting led by Nikolai Skorik at the Moscow State Institute of Culture, the MGIK, who started his own theatre in 2015). The production was performed in Vysotsky's House on Taganka, on 25 January 2018, to commemorate the unlived 80th birthday of Vysotsky. The production was directed by Vysotsky's younger son Nikita Vysotsky, their former pedagogue of the department of direction and acting MGIK. It is customary for him to recite his father's verses and give an account of his life before the performance begins.

Again, the production takes places on a simple stage composed of just several chairs. When it comes to the content and performance, Nikita Vysotsky opted for an intriguing form of his "production-concert" - he employed the letters from Vysotsky's fans of various age categories and of diverse professional background. The actors perform them as documentary verbatim theatre, with special focus on authenticity and on the unique ways of expression of the writers of different age groups, having diverse educational and regional backgrounds. By way of introduction, citations from letters are read into the microphone, with the words gradually ending

${ }^{32}$ The original title was Ya ne lyublyu kagda napolovinu! [I don't like anything half-done!], based on a line from Vysotsky's song Ya ne lyublyu fatal'nogo ischoda..." [How I detest the fatal final curtain...], (1969). 
up in a confusion. Next, each reads his/her letter to Vysotsky and then they sing or recite a poem by Vysotsky. Sometimes, other texts replace letters, for example, excerpts from Marina Vlady's book. There are instances, when the actor starts reading the text upfront, without Vysotsky's introductory word. A mosaic is pieced together of individual confessions spoken into the microphone. All texts and lyrics of songs are picked by actors individually, based on their affinity with them. The performers identify themselves with the texts/lyrics and at the same time, they are prepared to distance themselves from them any time. They sing and play to a musical instrument or they set up diverse intimate musical groupings. The actors who do not perform in a scene, stand motionlessly at the rear of the stage. In places, they evoke the milieu of the story which is being sung or talked about. In conclusion, a disorderly mingling of many voices is heard, just like at the beginning.

\section{Vysotsky's Songs like the Songs of Brecht}

Vysotsky's songs performed on stage repeatedly prove their dramatic sovereignty. But they can also live in the text of another playwright. This side of his songs was presented to the audiences in a graduation student performance Gorky. Dno. Vysotsky [Gorky. The Bottom. Vysotsky]. The production director, Boris Diachenko ${ }^{33}$, pedagogue of acting at Vysotsky's alma mater, at the MKhAT (Moscow Art Theatre) School-Studio, connected the text of Maxim Gorky's play The Lower Depths with the lyrics of Vysotsky's songs. The lyrics were to bring light into Gorky's text which he found too dark.

In 1960, Vysotsky successfully graduated from the Acting Department. He was cast in the role of an old man Bubnov in the play The Lower Depths. However, Diachenko does not pick up on this fact, as the character of Bubnov (and that of Kvashna, vendor of pelmeni, i.e. small pasta cakes) was deleted from the production. The first night of the "musical production" which he rehearsed with the actors, former students of Yevgeni Pisarev ${ }^{34}$, took place on 13 May 2016 at Pushkin Theatre' Small Stage. In the subsequent 2016-2017 theatre season, the production was listed on the theatre repertoire and it was also performed on the occasion of the unlived $80^{\text {th }}$ birthday of Vysotsky, on 25 January 2018. ${ }^{35}$

Diachenko moved towards Brecht's approach to epic theatre which was employed by Vysotsky at the Taganka Theatre. His songs in the production fulfil the function of Brecht's songs, which in his plays served as an instrument facilitating a dialogue with the audiences. The actors would perform on an empty stage, with but a few props, a book and bottles. The guitar, the symbol of Vysotsky, is also there. There is a small auditorium situated at the backdrop. Actors are seated there while visitors

\footnotetext{
${ }^{33}$ Between 1984 - 1989, member of the actors ensemble of the Taganka Theatre. In a renewed production of The Cherry Orchard by Anton Chekhov, direction Anatoliy Efros (1975), he cast the role of Lopakhin which had been cast by Vysotsky earlier on.

34 The pedagogue of acting Dmitry Brusnikin, member of the actors' ensemble of the Chekhov Moscow Art Theatre mounted a "production-concert" with his students featuring Vysotsky's songs and poems Vrubayem Vysotskogo [We Bang out Vysotsky].

${ }^{35}$ Its live transmission was broadcast on the Internet. It was a special performance, as this student production continued to be on the repertoire of the theatre only until the graduation of students towards the close of 2016-2017 theatre season.
} 


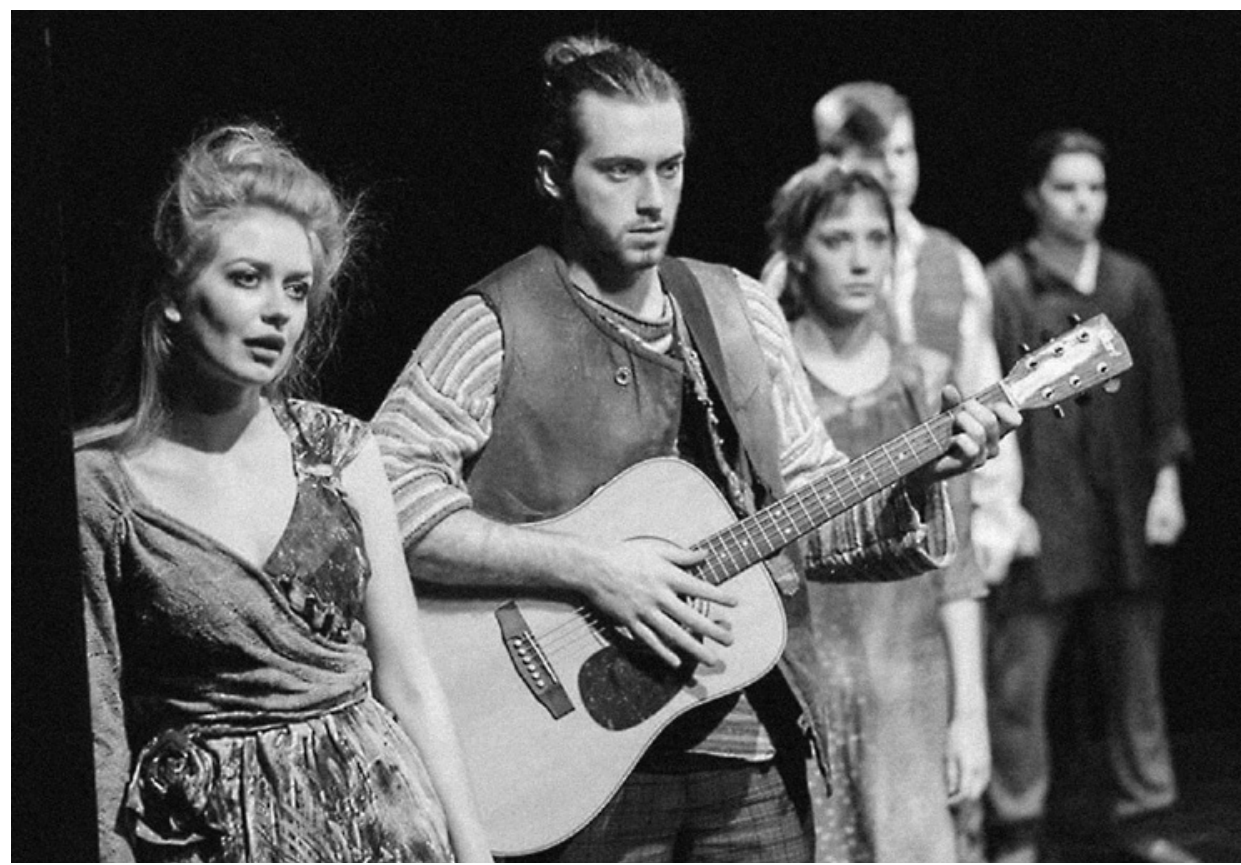

Maxim Gorky/Vladimir Vysotsky: Gorky. Dno. Vysotsky. [Gorky. The Bottom. Vysotsky]. Pushkin Theatre' Small Stage, premiered on 13 May 2016. Anastasiya Kalashnikova (Nastiya), Vladimir Ziberev (Baron), Veronika Kuznecsova (Natasha), Pavel Usachov (Tatarin), Ivan Semyonov (Kleshch). Direction Boris Diachenko. The director's private archives.

keep arriving and they are being silently watched. A parallel may be drawn with Hamlet where Vysotsky is seated on the stage before the arrival of viewers, or with the auditorium placed on the stage in a poetic commemorative composition directed by Lyubimov on Taganka Theatre.

In the opening moments, actors would rise from their seats to enter the stage. They start singing My vsje zhiviom kak budto... [We are all living like..., 1973]. The director maintains the principles of epic anti-illusive theatre and the distancing of actors from characters by letting young actors impersonate older heroes without masks or theatrical make-up or without acting stylisation. Throughout the storyline, they step in or step out of their roles. They do not leave the stage and when their scene is over, they take a seat on a bench placed on the side of the stage. From there, they would watch the performance of others. If their character dies, they go back to the auditorium where they were originally seated before the performance began. The performance opens with a Vysotsky's song and it is finished with a song. In conclusion, all actors sing his song Ochi chernye II, Chuzhoi dom, [The Dark Eyes II, The Strange House, 1974] - a house, especially an abandoned one, is among the dominating motifs of Vysotsky's songs.

Diachenko incorporated twelve songs by Vysotsky into the play's text. He picked well-known and less-known songs, especially of the early period of Vysotsky's creation (1961 - 1965), which belong to "blatnye pesni", or to underworld songs. The 
selection of lyrics is well-founded given the fact that Gorky's heroes are on "the bottom" of social ranking, on the edge of society. By selecting the songs, the director managed to create a solid superstructure over Gorky's text. The songs of Vysotsky eventually became the basis of the production rather than its complement. Moreover, it turned out that young actors were more confident in performing the songs than in performing the scenes. The songs provided them with an underlying theme they could build on and be more emotionally immersed in it while in acted scenes, they happened to lose focus of the character's theme and his/her motivation.

Dramaturgically, the songs match the themes of individual characters and their different nature. What brings them together is that they experience extreme, existentially and emotionally exacting situations. They surface the social dimension of Vysotsky's creation. The songs divulge a deep psychological layer of the characters in his songs that become united with the characters of Gorky's play. Through Vysotsky's songs, the characters may honestly and without fear name their dark past, their dreams and their future. Through them, they can express desires and emotions which are not expressed in the play's text and to show the richness of their inner worlds in which they find retreat, coveting for a better world.

\section{Vysotsky's Novel, Novel about Vysotsky}

Vysotsky was a song and poem writer, but he also wished to write prose, theatre plays and film scripts. Regrettably, these authorial ambitions were only met in part. For the most part, the text remained unfinished. It is clear, though, that in their creation he would be applying identical creative principles, motives and symbols as in the writing of lyrics and poems and in acting. On the stage of the Taganka Theatre the actor was expected to be more than just a performer of the role text, at the time of the production, he was also its author, which was a principle he also applied in film acting.

From June 1989 up until the present, there has been a production on the repertoire of the Moscow theatre At Nikitsky Gate, Roman o devochkach [A Novel about Girls]. ${ }^{36}$ It is a dramatization of the best-known unfinished prose by Vysotsky, most likely written in the late 1970s. It narrates the story of the former prospective actress and a later foreign exchange prostitute Tamara Poluektova. The plot portrays her relationship with a mobster Nikolai Sviatenko, nicknamed Colleague, and actor and singer Alexander Kuleshov. The author of the dramatization in two acts is the theatre director and artistic director Mark Rozovsky. ${ }^{37}$

As mentioned in the programme booklet, it is a production "about a time we used to live and we continue living today. It is about despair, about love. (...) A bitter spirit of the times is present in every line of Vladimir Vysotsky's song, in every stingy sentence. These phrases, one right after the other, surprisingly blend into a free and plain language. It reverberates in you, as if you were the one talking, thinking, and feel-

\footnotetext{
${ }^{36}$ The text was given its name at the time of its publishing in Leningrad monthly Neva, January 1988.

${ }^{37}$ Russian theatre director, playwright, actor, script writer, prose writer, poet, and composer. He studied journalism at M. V. Lomonosov Moscow State University (1960) and an advanced screenwriting course (1964). He made his name by the dramatization of Lev Tolstoy's short story The Story of a Horse, which he staged at the theatre At Nikitsky Gate in 1992. He founded the theatre in 1983. He embarked on his career on small alternative stages (during his studies at Moscow State University) and his theatre At Nikitsky Gate is a remnant of the alternative theatres movement.
} 


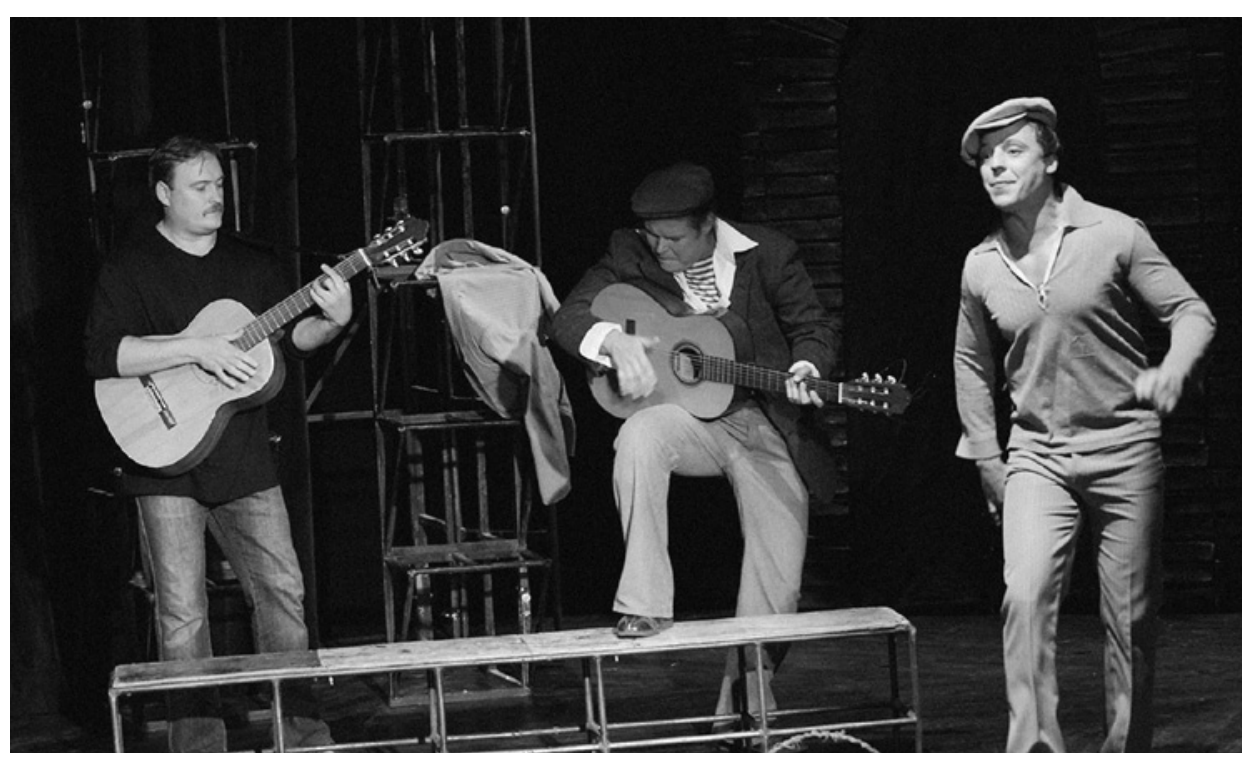

Vladimir Vysotsky/Mark Rozovsky: Roman o devochkach. [A Novel about Girls]. At Nikitsky Gate Theatre, premiered in June 1989. Denis Yuchenkov (Alexander Kuleshov), Vladimir Davidenko (Lyon'ka Sopel'a), Sergei Sholokh (Kol'ka Sviatenko). Direction Mark Rozovsky. Photo by Svetlana Mursi-Gudezh. Theatre archives.

ing. Moscow backyards, municipal flats, lockup, empty hopes. A ferocious system of millstones that are not being turned by someone at the top, by good-for-nothings, by executioners or by boot-lickers. Those millstones, it is us, each and every one of us. We are both the executioners and victims of ourselves." 38

Vysotsky's prose, just like his songs and poems, portrays the bitterness of life and the yearnings of the people of the post-war period. The rough conduct of his characters is a testimony of their inner injuries. Even though these are serious themes, they are full of Vysotsky's peculiar humour. Much like in his songs and poems, author Vysotsky demonstrates his sense of blending the comic and the tragic. In his direction method and in dramatization, Rozovsky employs the principles of Brecht's epic theatre. Tamara experiences her "Novel about Girls, the Love Story" 39 via her remembrances. They are brought to life in individual scenes, they are revivified against the backdrop of a Moscow backyard. Again, there is a brickhouse erected against the backdrop. The plot of one scene overlaps with the other and characters move from scene to scene. Some actors perform several roles simultaneously, they step out of the plot to comment on the situation and to clarify their motives or action.

It goes without saying that several Vysotsky's songs were incorporated in the dramatization $^{40}$ - for instance, the song of the criminals Rebyata, napishite mne pis-

${ }^{38}$ Teatr U Nikitskych vorot. Roman o devochkach [programme booklet]. Moskva : Teatr U Nikitskych vorot, year of publishing and page number not specified.

${ }^{39}$ Cit. according to http://www.teatrunikitskihvorot.ru/spektakli/roman_o_devochkah/ [4 May 2018].

${ }^{40} \mathrm{~A}$ folk song and a musical motif by Ennio Morricone are incorporated in the musical dramaturgy of the production. 
mo [Guys, Write Me a Letter, 1964]. The lyrics of a lyrical song Lyublyu tebya seychas [I Love You Now, 1973] are recited by Nikolai to Tamara as a little love poem. Before the intermission, Kuleshov sings the last of Vysotsky's songs Grust' maya, taska maya [My Sorrow, My Anguish, 1980].

The songs are mostly performed by the character rendered by Kuleshov, an actor with a husky voice, who composed and sang songs to the guitar. The character is a clear autoprojection of Vysotsky in the story of the novel. When Kuleshov sings his songs into the microphone, it is as if he simultaneously performed the role of Vysotsky. The identification of Kuleshov with Vysotsky is enhanced by Vysotsky incorporating the myths about his own life into the character. For instance, he brings to life the generally known myth circulating among the prisoners. They believed that Vysotsky must have been incarcerated, how else could he have written songs so accurately depicting life behind bars. Even prisoner Nikolai, alias Colleague (Tamara's sweetheart from the house where she lived), believes that Kuleshov must be Vysotsky's inmate. He claims that it is his songs that make life easier behind bars. He becomes his idol, but he does not have an inkling that Tamara starts dating him while Nikolai is in prison. Denis Yuchenkov portraying Kuleshov steps out of character and becomes the author of the novel (written from the narrator's perspective). He walks on the stage like Vysotsky, who observes characters and the storyline he had written. However, this level is merely implied.

\section{The (Re-)Birth of a Legend}

A comprehensive view of Vysotsky's life and authorial work, the stratification of themes and dramatic potential, is offered by an epic documentary musical production running almost four hours long, the musical Vysotsky. Rozhdenie legendy [Vysotsky. The Birth of a Legend]. The Moskovsky Gubernsky Theatre put it on stage on the occasion of the unlived $79^{\text {th }}$ birthday of Vysotsky, on 25 January $2017^{41}$ as a "tribute to an immense talent and genius, Vladimir Semyonovich Vysotsky, to his art of confession." 42

Sergei Bezrukov, script author, director and one of the actors performing Vysotsky (a very popular theatre and film actor who also impersonated other big names of Russian poetry, such as Yesenin and Pushkin), collaborated with the V. Vysotsky State Cultural Centre-Museum "Vysotsky's House on Taganka". The reproductions of numerous archival materials were put to use on the stage. The production employed backdrop projection, with copious family photos of Vysotsky, clips of documentary films and shows in which he performed, for instance, from his last television concert Monologue, given in January 1980 (Monolog, Sovetskoe Televidenie. Gosteleradiofond Rossii). There are scaled-up replicas of posters hanging over the stage, featuring productions in which Vysotsky was cast in leading roles, Hamlet, Ten Days That Shook the World, The Life of Galileo. There are shawls with the photos of Vysotsky, largely the portraits of his film roles and record covers, etc. hanging on the stage sides. A copious source of biography information in the play's text is the biography Vysotsky written

\footnotetext{
${ }^{41}$ The premiere took place at the State Kremlin Palace. The theatre considers the staging of this play invariably on the $25^{\text {th }}$ day of month.

${ }^{42}$ Cit. according to http://m-g-t.ru/performance/vysotskij-rozhdenie-legendy [1 May 2018].
} 


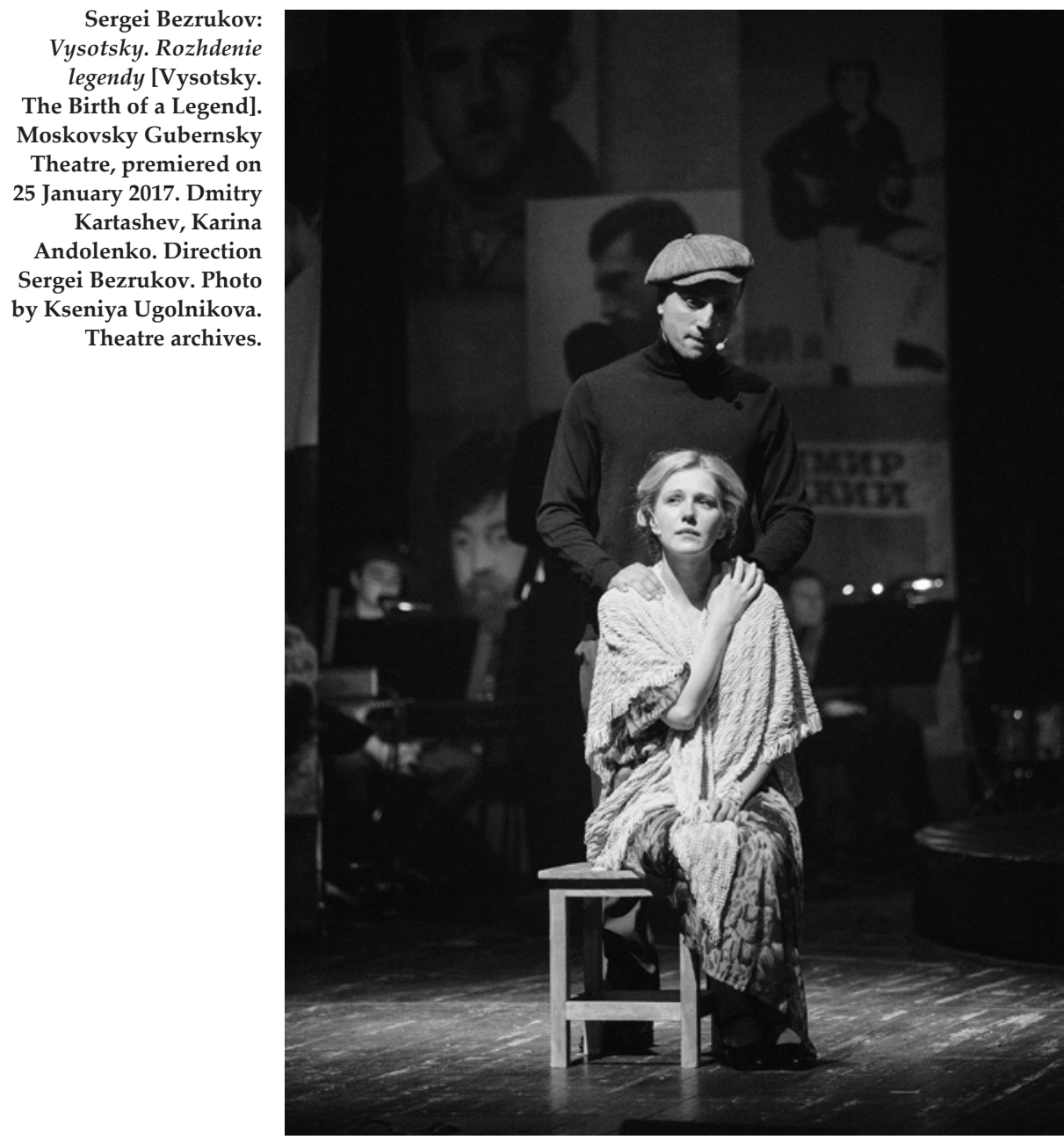

by Vladimir Novikov for the edition Zhizn'zamechatel'nykh lyudey [The Life Stories of Outstanding People]. The fragments excerpted from diaries and letters were also used.

The production opens up with the recording of a theatre survey carried out in the Taganka Theatre. Vysotsky is asked who he would like to be. He replies: "Vysotsky." The opening dance choreography of actors rendering Vysotsky is a re-enactment of his famous monologue of Khlopusha in Pugachev. The story portrays the life of Vysotsky from his childhood. Persons from his private and professional lives enter the stage (Yuri Lyubimov comes, too). The images of recollections bear headings, as if chapter titles of a book, i.e. Mum, Father, Mum Zhenya, etc. The titles are shown during the projection together with their photos and the photos of Vysotsky from that time period.

"Vysotsky Theatre" of songs and poems is presented on stage as parables of life and of a time when the artist lived, by showing the paradoxes of the era. A powerful mo- 
ment is that of taking a decision on the granting of visas to Vysotsky. Vysotsky's visa application was to be clearly turned down by the officials, but one of them has a vinyl record of his songs ready to be secretly autographed. He is Vysotsky's secret fan.

The production features songs covering all Vysotsky's cycles. A broad range of characters and stories in his lyrics build Vysotsky's personal portrait, show his empathy, valour, passions, and a sense of humour. He remains the main hero of his songs, although he does not always appear in them. Bezrukov locates them in the middle of the stage, using a revolving stage of the shape of a gigantic revolving gramophone record. His songs are performed in other than usual contexts. For example, his Ballada o lyubvi [Ballad about Love, 1975], is not to be understood as Vysotsky's confession of love of a woman but rather as a mutual confession of love between his parents.

The timelessness of Vysotsky's songs is highlighted thematically and musically. The direction and dramaturgic concept of the production employs songs in genrewise diverse and unconventional arrangements, from classical bard performances with a guitar, through the 1970s orchestral arrangements, down to an utterly modern rock sound. Alongside twenty-four actors, there is a numerous Gubernsky Orchestra of Moscow Region performing on the stage (orchestra director Sergei Pashchenko). In the penultimate scene the stage is converted to a concert stage. Actors enter the stage in modern costumes and sing Vysotsky's songs in modern staging, one is even a rap version.

After the concert is over, the storyline returns to Bukhara (Uzbekistan), where he survived his second clinical death on 25 July 1979, exactly a year before he passed away. The scene is accompanied by shots from Vysocky. Spasibo, chto zhivoy [Vysotsky. Thank God, I'm alive] ${ }^{43}$, with Sergei Bezrukov performing Vysotsky. ${ }^{44}$ Vysotsky is shown laying on a hotel bed in Bukhara, praying to God to look after all his loved ones. Actors performing the characters enter the stage in sequence as called by Vysotsky. They face the projection to bid farewell.

\section{Vysotsky's Time to Sing}

On the occasion of the unlived $80^{\text {th }}$ birthday of Vysotsky, the Taganka Theatre staged the dramatization of the fairy tale Alice in Wonderland by Lewis Carroll. It was put on stage as a music comedy Begi, Alisa, begi [Run, Alice, Run]. The preview was held on the 25 January 2018 and it was premiered on 2 February 2018. Eight Vysotsky's songs composed for a radio play of the tale in 1973 were incorporated in the dramatization. ${ }^{45}$ The production was directed by Maxim Didenko, a distinct personality shaping contemporary theatrical language that ties into the Russian traditions of interwar avant garde, while capitalising on a deep knowledge of modern western theatre. He has perfectly mastered the methods of work with modern technology (projection, media, etc.) and is a perfectionist when it comes to actors' work.

In the production Begi, Alisa, begi, Didenko employs the fairy tale's basic conflict, the fight between the good and the evil. However, this distinction is not viewed in

\footnotetext{
${ }^{43}$ Direction Piotr Buslov, Direkciya Kino, 2011.

${ }^{44}$ Dubbed by Nikita Vysotsky.

${ }^{45}$ Direction Oleg Gerasimov, Melodiya, 1976. Vysotsky is the author of music and lyrics, he performed roles Parrot the pirate and Young Eagle Ed.
} 


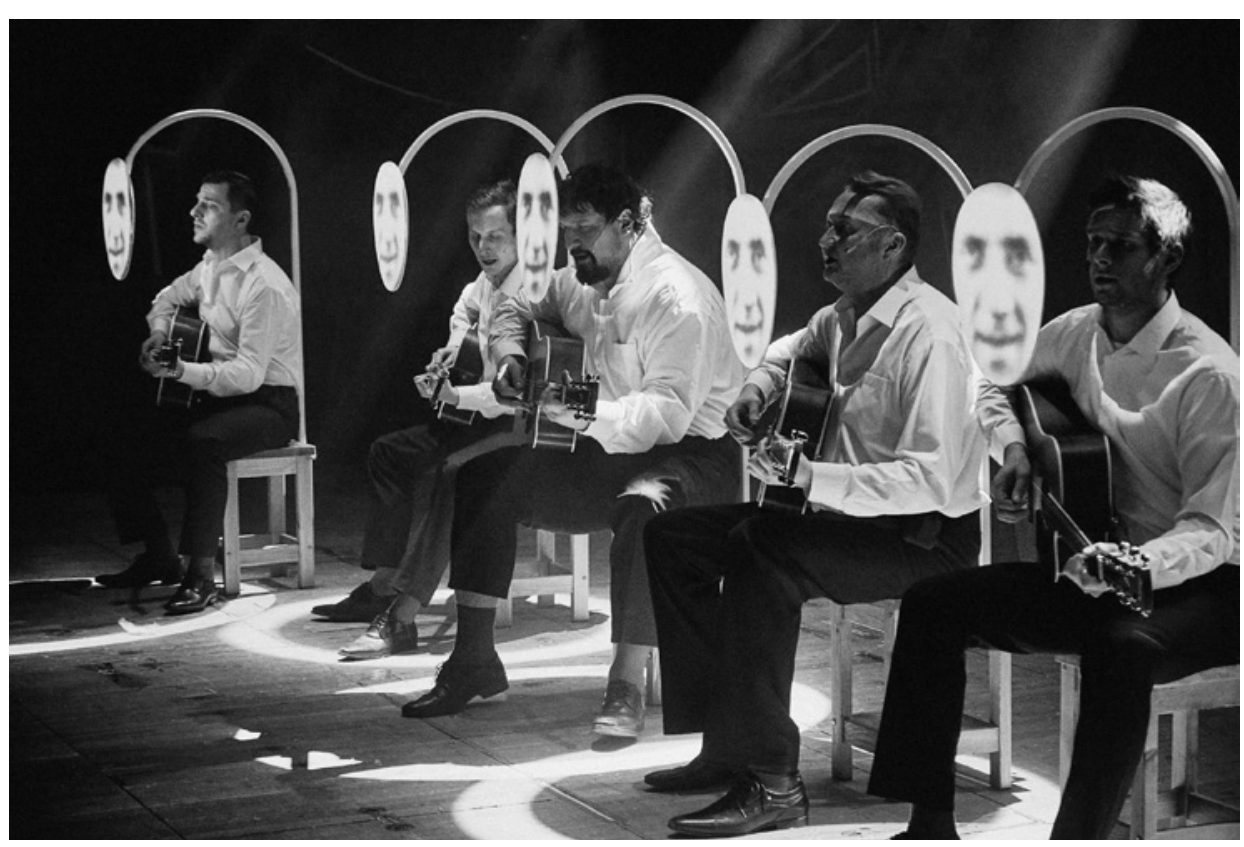

Lewis Carroll/Vladimir Vysotsky/Valery Pecheikin: Begi, Alisa, begi [Run, Alice, Run]. Moscow Theatre of Drama and Comedy on Taganka Square, premiered on 2 February 2018. Dmitry Vysotsky, Roman Kolotuchin, Konstantin Lyubimov, Sergei Ushakov, Alexandr Metelkin. Direction Maxim Didenko. Photo by Sergei Trifonov. The photographer's archives.

conventional black-and-white colours, as is the case with tales. The central theme is the ambiguous nature of the issue of guilt and innocence. Just like any person, Alisa, too, has the light side and the dark side that haunt us no matter where we go. We have to fight them all our lives. In this context, Didenko advances the story of Alice impersonated by three heroines (a little girl, a young girl and a grown-up woman) to a level of a political tale about the absurdity of trials. He draws from the motif of Carroll's story, in which the Red Queen, epitomising Russia, puts to trial everyone who does not live according to a template. Therefore, the only colour in a black-and-white stage design is red colour. The director also alludes to a current trial with a popular theatre and film director that attracts a high level of public attention. Kirill Serebrennikov is the leading personality of Gogol Centre in Moscow and he has been charged with the embezzlement of funds granted for Platforma project. Since 2017, he has been in house arrest (the theatre public believes that the charge is politically motivated).

Towards the close of the production the urge to try distinctive personalities is linked up with Vysotsky's fate and persecution for his songs. Vysotsky enters the stage as one of the characters of the Red Kingdom and author of the fairy tale. He is performed by a member of the drama ensemble of the Taganka Theatre, by his namesake Dmitry Vysotsky. He is clad in a dark costume, which evokes Hamlet's costume and clothing typical of the Taganka actors of Vysotsky's time. He wears a big head with Vysotsky's face. Over-dimensioned body parts weave through the entire production, alluding to Carroll's fairy tale, or in general, to fairy tales and children's toys which 
oftentimes have big heads, face or body details to catch attention. Vysotsky's character, from the position of an author, reassures Alisa that when "bad" Alisa shows up again, they will have to fight one more time, but she will defeat her, just like she has today. Alisa is telling him that the story has happened somewhere and that she has already seen him somewhere. According to Vysotsky's words, it turns out that the fairy tale about Alisa that has happened is, in fact, a story from one of his songs. Seven actors enter the stage with guitars and together they sing Vysotsky's song. There are medallions with the projection of the singing face of Vysotsky hanging in front of their faces. As he said to Alisa: "I often sing songs. I love my job. This is time to sing!"

\section{The Hero Vysotsky}

As seen from the most recent production of the Taganka Theatre dedicated to Vysotsky Begi, Alisa, begi, the time for his singing has not yet come to an end and his works and legend continue to live on. All the above plays demonstrate that Vysotsky's personality and work continue to raise the interest of theatre makers, professional and the general public. The endeavours to bring to life the cult of Vysotsky's personality on stage have been present in theatre since Soviet times. Let us bring to mind the production of a comedy in two acts by the Soviet playwright, screenwriter and prose writer Mikhail Roshchin Sedmoy podvig Gerakla. Avgievy konyushni [The Seventh Feat of Hercules. Augean stables, 1963, published in 1987], in Moscow Sovremennik-2 Theatre (young actors theatre), in 1988. The hero Hercules who arrived in an allegedly prosperous ancient land which eventually turned out to be a place of hypocrisy and rottenness with everything subjugated to Ata, the goddess of falsehood, was rendered by Nikita Vysotsky, the son of Vladimir Vysotsky. Theatre and artistic director Mikhail Yefremov put to use the father-son resemblance, which was further enhanced by the stylisation of movement and the diction of Nikita mimicking his father. An impression was created that it was Vladimir Vysotsky himself performing Hercules and a metaphor of Vysotsky as Hercules suggested that he was the only one who could clean up the stables and bring order into a country ruled by pretence.

This version of the interpretation of the myth of Vladimir Vysotsky from the Soviet era brought to the fore a persisting powerful image of Vysotsky as an invincible hero. He embodied an advocate of right beliefs and warrior for justice who can avert the state of desolation of the outer and inner worlds of helpless people. Theatre professionals follow this image and the audiences ask for it. A second strand of interpretation of the cult of Vysotsky's personality is the portrayal of Vysotsky as a victim of the era and of the political regime. His lyrics make it clear that the then regime had many more such victims among both the artists and "ordinary" people. When researching on these interpretations, the generational and aesthetic stratification of individual creative professionals is brought to attention. Vysotsky's personality and work are reanimated on the stage by both the contemporaries of the "old" Taganka (Lyubimov, Gubenko, Zolotukhin), and markedly younger directors (Tugushev, Diachenko, Rozovsky, Bezrukov, Didenko or Nikita Vysotsky). The power of his personality and dramatic qualities of his work are studied on big and small stages, in line with the traditions of the school of psychological realism of Konstantin Stanislavski, the theatre of the Russian interwar avant garde, epic theatre, and also with the devices of 
modern drama and documentary theatre. In a peculiar way, every production surfaces the dramatic nature of Vysotsky's songs and poems, which asserts the essence of his creative personality. He was a poet "born out of theatre" 46 and, therefore, his work belongs to the theatre.

The study is an output of the SRDA project No. 15-0764, Slovak Theatre and Contemporary European Theatre Culture, Continuity and Discontinuity.

Translated by Mária Švecová

Zuzana Spodniaková

Ústav divadelnej a filmovej vedy CVU SAV

Dúbravská cesta 9

84101 Bratislava

Slovakia

e-mail: spodniakova.zuzka@gmail.com

${ }^{46}$ KRYMOVA, Nataliya. O Vysotskom. In Avrora, 1981, Issue 8. Cit. according to KRYMOVA, Nataliya. Imena. 1972 - 1986. Tom 2. Moskva : Trilistnik, 2005, p. 254. ISBN 5-89480-064-1. 